\title{
Displacements in the Context of Social Crises in the Oil-Rich Niger-Delta of Nigeria and Oil-Rich Bakassi Peninsula in Cameroon
}

\author{
Fayomi Oluyemi \\ Covenant University, Department of Political Science and International Relations, School of Social Sciences, \\ College of Development Studies, Ota, Ogun State, Nigeria \\ *Corresponding Author: olu_fayomi@yahoo.com
}

\begin{abstract}
The Niger -Delta constitutes Niger's —oil belt' that lies along the Guinea coast of the country. The region sits on top of about 176 trillion cubic feet of gas and about 35.2 billion barrels of oil reserves. It also accommodates 20 million people which belong to more than 40 ethnic groups. Similarly, the oil-rich Bakassi Peninsula in the Western Cameroon juts into the Gulf of Guinea. Adjacent to the border between Cameroon and Nigeria, the Bakassi Peninsula was the subject of a long distance diplomatic dispute between the two countries until 2002. The swampy Peninsula, cut by series of channels, covers an area of $50 \mathrm{sq}$ $\mathrm{km}$ and has large untapped reserves of petroleum. Nigeria and Cameroon have disputed over the possession of Bakassi for some years, leading to considerable tension between the two countries. In 1981, the two countries were on the verge of war over the oil rich peninsula. This paper discusses both theoretical and empirical perspectives of patterns of displacement of people as a forced/involuntary migration in Nigeria and Cameroon. This perspective is based on a forcesubject-migration reasoning.
\end{abstract}

Keywords Social Crises, Displacement, Migration, Conflicts, Niger-delta Introduction

\section{Introduction}

It is pertinent to note that the extent of displacement in Nigeria has increased greatly in the past few years leading to the increase in the number of displaced people. In this present dispensation, the displacements of people in Nigeria are evident in the ethno-religious conflicts in the North, conflict over the distribution of rural development projects, election result crisis, and conflicts arising from crude oil exploration in the Niger Delta areas.

Taking a cue from the Pre-colonial times, it was observed that the rebellion broke out in the Niger-Delta area over the exclusion of indigenes from trade in palm oil. In the past few years, social relations in the Niger-Delta region have been marked by continuous conflicts, some of which are re-emerging old conflicts, while some are the outcomes of recent development in the Nigeria's socio-political terrain. What is evident in this study is the conflict surrounding the oil industry. According to Eze (2009), states that this negatively affected socio-economic activities in the region, leading to a high level of insecurity, a disruption of oil production activities and the evacuation of expatriates who are the main target of kidnapping or hostage taking. The conflict blamed on natural resource struggles escalated in February, 2006 with the commencement of the armed militias which have used violent means to gain control of oil wealth and criminal activities, clashing with the Nigerian Army, kidnapping of numerous foreign workers and destruction of installations, culminating in the reduction of Nigeria's oil output by one-fifth.

In the Niger- Delta area, displacement has been closely linked to oil exploration and production. While the area has been volatile for many years, with impoverished local communities accusing successive governments as well as multinational oil companies of depriving them of their fair share of revenues. In some of the heaviest clashes in the area in September, 2008, between the national army and members of the Movement for the Emancipation of the Niger- Delta (MEND), civilians were caught in the crossfire and two villages were allegedly razed to the ground forcing up to 20,000 people to flee. Violence between local militia groups and security forces, as well as inter-militia fighting and widespread destruction of property, has frequently forced people to flee their homes. Oil- related environmental problems in the area have also been linked to increased population movements.

There has been a continual presence of military and police detachments, systematic state repression which may take the form of extra-judicial killings. The conflict situations have been between the oil prospecting multinational companies and indigenous communities; the government of Nigeria and the indigenous population; and among the indigenous or local communities. In the borders of both Nigeria and Cameroon Bakassi Peninsula has been a disputed piece of ISSN: 2332-6840 (Online) 2332-6832 (Print) Copyright (C) 2014 Horizon Research Publishing 
territory between Nigeria and Cameroon for decades and the genesis of several conflicts in 1981 and the early and late 1990s. The discovery of potential oil reserves in the waters surrounding the Peninsula heightened tensions between the two countries. Mbuh (2004) referring to Africa Confidential (1994), Mbuh (2004) states that "Nigeria's...decision to deploy thousand troops on the peninsula was in turn a reaction to the harassment of Nigerian fishing vessels and traders by Cameroonian Gendarmes . The International Court of Justice (ICJ) decided on October 10, 2002 that the Peninsula and territory in the Lake Chad region should be under sovereignty of Cameroon. Nigeria agreed to pull out of those areas by September 2004. It has given up 32 villages along the $1,700 \mathrm{~km}$ border from Lake Chad to the Gulf of Guinea, but had a military presence in Bakassi until the official handing over to Cameroon in August 14th, 2008. This border dispute gave rise to various issues such as external displacement of people leading to the question of citizenship of the thousands of Nigerians now living within Cameroon territory, and the development of offshore oil reserves near the Bakassi.

\section{Conceptualization}

In the theoretical discourse on displacement, the conceptual dominant perspective defines the problem of displacement as one of "forced/involuntary migration". According to Ibeanu (1998), the force-subject-migration perspective on population displacement has many inherent weaknesses. In the first place, at a purely theoretical level, it treats force as being of the same magnitude in all cases. It is not clear whether a different quantum of force or the same amount of force in all circumstances or in different circumstances yields the same result which is migration. Secondly, it does not consider the varying capacities of subjects to absorb or contain force generally. Finally, it treats all displacements as being of the same spatial dimension.

Several reasons have been given ascribed for the movement of people from one location to another. Imolehin (2007) discusses the reasons for movement could be for the purposes of moving into the - greener pastures: for employment, better economic and educational opportunities or indeed could be mass movement from a crisis area to a relatively peaceful area as a result of socio-political or religious chaos. A country may decide to change her administrative capital from one city to another within the country while an office may decide to change its headquarters from a geographical zone to another for a variety of reasons. For whatever reasons, movements take place with consequences for demand for social and economic facilities in the new places. It is then apparent that people will always be on the move during such occurrences.

Imolehin (2007) further expatiates on the issue with other reasons which include the denial of human rights and lack of access to educational and health facilities including denial of political rights. People want to come out of poverty. Their present environment may be harmful, damaging and degrading and threatening to human existence or health. They want to move to places where there is hope of better opportunities and where they are sure of sustainable development and achieving their full potentials. Such movements could be within the country i.e. from one state/region to the other occasioning in population shifts leading to obvious impacts on the areas moved to and the areas vacated because of a battery of human activities that is triggered due to the movements.

In terms of proclivity, Ibeanu (1998), is of the opinion that the displaced people rarely contest their predicated and only in a few celebrated cases, like that of the Bakolori peasants who were displaced by a dam in the 1980s and the Ogonis whose livelihoods are threatened by oil exploration, have internally displaced people organized and effectively put their condition on the political agenda. The lack of organization among displaced people generally serves to keep their plight concealed.

While studying the literature on the mediation during cross-border crisis situation that leads to displacement, Guy-Michel (2004), notes that it is important to emphasis on the various actors that are intervening in the area that experience difficulties. When they have the tools and capacities necessary to put their ideas into practice, they often run into trouble procuring funds that are earmarked for strictly national projects. Moreover, these actors often confront problems associated with norms and procedures that do not yet take into account the regional conditions established by the treaties between West African countries. The gap between theory and practice in the field of integration thus persists.

In this context, it is not uncommon to see different actors, beginning at the level of state representatives, disregard certain regulations in order to resolve cross-border conflicts and issues, relying instead on local customs and authorities (as in the case of bamboo management between Senegal and Guinea-Bissau, as well as in the handling of livestock theft and animal health...). The numerous actors encountered by the mission also indicated that the development of local agreements was the most efficient form of regulation.

Guy-Michel (2004) further emphasizes that various forms of local mediation, which are either being utilized on an ad hoc basis or are in the process of being institutionalized, contribute to strengthening cross-border approaches, and to attenuating tensions that are potential sources of conflict. At the same time, a number of contacts and exchange networks are forming and enlarging our understanding of cross-border tensions and complementarities. The utilization of this knowledge within the frameworks of exchanges, projects, programs remains limited and thus constitutes challenge to be met. Some local organizations are in contact with organizations on both sides of the border.

This is the case, for example, with the Foddé NGO, which possesses a cross-border program, and with the Youth Movement for Peace and Integration, which undertakes 
some very specific cross-border activities. But such examples remain few. Changing the scale and scope of these various activities seems to represent the next major threshold to be crossed.

However, to accomplish this will require assisting stakeholders in the cross-border project to more effectively confront national, regional, and even international problems, by developing a large network that will facilitate the process of de-compartmentalization.

In view of the analyses, cross-border approach thus continues to respond to a social reality, undistorted by the prism of certain "developers," but it remains barely operational within processes of formalization. The necessary labor required for changing the approach so as to better incorporate the perspectives of regional stakeholders, beginning with administrational ones, therefore remains not only relevant but the substance of a long-term project.

\section{Dynamics of Displacements in Niger-Delta and Bakassi Peninsular}

The oil rich Bakassi-Peninsula stands out as the most serious crisis of all the border disputes that Nigeria and Cameroon have had since the independence of the two countries. This portion of the disputed border draws increasing attention, as it also became public knowledge that the peninsula is very rich in petroleum and natural gas.

The display of arms and ammunitions has left many dead and wounded and displaced. Fighting occurred on the lands surrounding the peninsula, (which are equally disputed), on the peninsula itself, and on the sea. The big question that faces both nations during the crisis situation was that of sovereignty over the mineral rich peninsula-and in response to this question, countries resorted to the use of military force to claim the territory.

Mbuh (2004) notes that the military struggle between the two countries resulted in some form of partition of the islands. Given the disadvantage that Cameroon's population which is about one-tenth that of Nigeria (as at 2008 roughly 1 million to 140 million), it is no surprise that Cameroon naturally accused Nigeria for using its population advantage to populate the Bakassi peninsula that could be seen as a tactic of claiming ownership.

From the Nigerian end, it was common to hear accusations of Cameroon Gendarmes and their tax-driven assaults on Nigerians living in the Bakassi peninsula area. Thus ,Cameroon initially claimed it had to exercise its sovereignty and protect its territorial integrity by taxing those who live on its soil, and Nigeria, while not relinquishing its claims of sovereignty over the peninsula had to send in troops to protect its citizens from Cameroon aggression.

The dynamics of Nigeria -Cameroon crisis over Bakassi peninsula escalated with incidents of incursion that led to shooting in which many casualties and deaths of both the soldiers and civilians of the two countries were recorded. But is should be noted that the numbers of the displaced Nigerian and Cameroonians living at the borders were not recorded.

Mbuh (2004) describes the striking first and second incidents that led to the conceding of the oil-rich area to Cameroon and these include the hostility that broke the stalemate over Bakassi Peninsula on February 18-19, 1994. It was after this incident that Cameroon decided to take the border dispute to the ICJ for its adjudication. Cameroon's application was deposited on 29th March 1994; amidst accusations from Nigeria that Cameroon was not committed to bilateral negotiations to resolve the matter locally. A second notable incident that escalated the dispute was recorded on February 3, 1996.

It should be emphasized that the strategic importance of the Bakassi peninsula and the increasing awareness of this same factor have been at the core of escalation. Jeune Afrique (1996) in its November 13, edition, it was noted that "...tous les ingredients d'un conflict majeur sont reunis"--emphasizing the point that all the factors that lead to a major conflict are present in the Bakassi peninsula dispute. Furthermore, the editorial notes "...les enjeux economiques et strategiques sont autrement importants..." in stressing the strategic economic importance of the peninsula as a factor for escalation of the crisis. The article further expresses the fact that the region harbors two very important seaports-Douala and Calabar, with a total of five million inhabitants, and for the developed countries with petroleum companies operating in the area, the risk of a major war are frightening. Noting the importance of the region to the French, the editorial did not hesitate to comment on France's "l'alternative $d u$ diable," which has provoked much criticism from the Nigerian side.

According to Mba (1995), the reason Nigeria and Cameroon suddenly find each other fighting over Bakassi for the most part seemed to hover over the identity crises surrounding the State of Southern Cameroons. The position of the Southern Cameroon Restoration

Movement (SCARM) and the Ambazonian Republic leaders has been made clear on numerous occasions, including their 1995 visit to the UN in demanding adult membership of that World Body. Concerning Bakassi, the position of the leaders had equally been cleared that from 1919-1958 when Southern Cameroons was jointly administered with Nigeria, the maps prepared by the Federal Ministry of Lands and Surveys in Lagos recognized the Bakassi peninsula as being part of Ambazonian territory. There was a belief that for the short duration of the Federal structure that the Southern Cameroons adopted after the Plebiscite, the Federal Cameroon Republic had Bakassi as part of it Federal Territory.

\section{Environmental Perspective to the Crisis in Niger-Delta and Bakassi}

The Niger Delta is a crisis ridden and an unstable area of Nigeria, access to oil revenue has trigger off violence and 
inter-ethnic clashes are common. Pipelines are regularly vandalized by impoverished residents, who risk their lives to siphon off fuel. Vandalism is estimated to result in thousands of barrels of crude oil wastage every day - a loss to the Nigerian economy of millions of dollars each year. Nigeria is the world's sixth largest oil-producing nation. However, mismanagement and successive military governments have left the country poverty-stricken.

There is an inevitable and serious conflict of interest between Delta communities that bear the environmental damage of oil extraction and the rest of the nation for which oil money is essentially a free good. Delta populations, clearly a minority, regularly lose these struggles. Had they some authority over environmental issues, many current problems might be more manageable. Lacking this, and given the federal government's control over all subsurface resources as well as -ownership of all land, all Delta issues inevitably become national issues. The national government has failed to resolve these. In its campaign to - buy off Delta discontent on the cheap, earlier administrations frequently corrupted Delta community leaders. There is a deep distrust in the Delta concerning the federal government and a feeling among local populations that most other Nigerians care little for their problems, so long as the oil flows. Delta populations constantly campaign for a larger share of the federal cake, most of which originates in their homelands.

As a result of these factors, and because oil companies did and do make tempting targets, many aggrieved youths in the Delta resort to direct action to extract compensation for their perceived losses. They invade oil company properties, take employees hostage, and shut down facilities. Oil companies typically negotiate release of captured personnel and properties with relative ease by paying the youth's modest ransoms. This oil company strategy creates a -moral hazard : the willingness of companies to pay ransoms stimulates imitators of this lucrative - business, leading to sustained disruptions, at times to competition among youths, and to a general sense of anarchy in the Delta.

What is closely linked to federal control over Delta oil and the economy in general is the intense competition for political office. For politicians, and for their communities, control of federal office opens the high road to resources that can be diverted from public to private or community control. Competition is naturally intense for federal political offices and has historically turned violent in the second election in each of Nigeria's two previous republics. In summary, federal control over oil and much of the rest of the economy tends to federalize many economic problems, particularly in the Delta, and stimulates intense efforts to gain and hold office throughout Nigeria.

Nigeria has a multitude of religious, ethnic, political lines that had led to violence and degenerated into internal displacement. During the 1999 elections for example, at least, 10,000 people died. The past two years have witnessed an alarming upsurge in the level of violence in the oil producing Niger Delta region, which has resulted in the internal displacement of the people in the region. Onduku (2003) describes the situation in Niger

Delta as that of oppression because to a considerable extent, the locals in the Delta swamp still live in primitive conditions alongside with the high tech and modern facilities of the multinational community they play host to. The story of the people is one of subjugation of indigenous people's rights by successive ruling governments. They have been raped of their resources and the wealth gotten from the region is still being looted and plundered. There seems to be collusion between the government and the western commercial interests against the inhabitants and any sustainable development effort for peace in the region.

Price (2005) describes the crisis over the Bakassi Peninsula and other border areas between Nigeria and Cameroon to have revolved around the environment and the possible resources that could be acquired by each country from the environment such as oil and rich fisheries. There is both a direct and indirect impact the environment has had on the conflict: each country would directly benefit from the undeveloped oil reserves in the Bakassi region, but the land disputes in the Lake Chad region had displaced fishermen as a result of drought and desertification.

Kirchner (2004), also notes terms of environmental issues, in recent years Lake Chad had been flooded numerous times, forcing local fishermen to either become farmers or move with the changing shoreline, causing them to cross international borders in the process. This has further exacerbated nationalistic tensions in the region and further displacements of the people in the area. The government of Nigeria's formal handover of the Bakassi peninsula to Cameroonian authorities on the 14th of August, 2008 led to the displacement of people.

Thousands of Nigerians residing in Bakassi fled to Cross Rivers and Akwa Ibom State in Nigeria because of security implications. Most of the returnees left without personal items. They also lost their monies and properties due to violent attacks. It should be noted that despite the substantial efforts made by the local authorities in Akwa Ibom state for the purpose of providing makeshift camps, the support provided does not meet all of the returnees' immediate needs. Majority of the returnees are from now concentrated in Akwa Ibom state and small number of them could be found in Cross Rivers State. Since the influx of the returnees to the two States the Nigerian Red Cross Society (NRCS), with the support from their volunteers, has been receiving the returnees and providing them with limited assistance in temporary facilities or camps which were provided by the local governments of the two countries.

\section{Implications of these Social Crises for Community Development, Social Work and Capacity Building}

The handover of Bakassi to Cameroon by Nigeria is a 
clear example of precautionary diplomacy and the peaceful settlement of border disputes. The two countries are moving in the direction of adoption of a treaty of friendship and non-aggression. Also, the two countries have shown an example of the potential for moving from a culture of reaction to a culture of peace. The Nigerian government announced its unpreparedness for the tens of thousands of returnees who were displaced from the Southern Bakassi province and there has been a call for the United Nations to handle the unexpected return of the externally displaced people.

According to the IRIN (2008), up to 76, 000 returnees registered at the twelve sites in Akwa Ibom and Cross Rivers States. This is the statistics given by the local government chairman of Mbo, Victor Antai. Cornwell (2006) observes that International debt relief has so far failed to convert into any real benefits for the ordinary Cameroonian, and this has created a crisis of expectations. The implementation of the Bakassi judgment may pave the way for some relief on this front, if the rumored oil bonanza is realized. Whether this will prove an altogether unmixed blessing for the people of Bakassi itself remains to be seen.

Indeed, the economic significance of Bakassi to the West African sub-region is significant. However, Nigeria's seeming geographic disadvantage over the Bakassi Peninsula actually holds abundant economic, political, and social benefits for the Giant of Africa. Bakassi in Cameroon's hands equally holds out substantial economic significance to Nigeria even though Nigeria has only a seaward access to Bakassi which could promote the harnessing of

Nigeria's maritime potentials in an environment of peace, and at the same time promote Nigeria's naval operations as conflict in the waters and the peninsula become nonexistent. The Cameroonian government being at liberty to manage the natural resources of Bakassi eliminates administrative costs of the peninsula to Nigeria and extends a necessity for beneficial consultative interests.

The development of Bakassi peninsula by Cameroon will totally bring an end to conflicts around the peninsula; activities of sea pirates, smugglers, and human traffickers will become eliminated as joint Cameroon-Nigeria border patrol steps in. Joint border oil exploration will equally benefit Nigeria while reducing the cost of oil exploration resulting in practical economic cooperation. Overall, economic cooperation with Cameroon will protect Nigerian residents in Bakassi, the larger Cameroon Republic, and all Francophone countries by extension.

With successful transfer of the Bakassi Peninsula to Cameroon vide ICJ judgment lies responsibilities on the part of Nigeria and Cameroon to maintain the status quo as sacrosanct and pursue the issue of coastal governance for the benefit of the inhabitants, such as: securing for the inhabitants a quality of environment adequate for their healthy living and well-being; conserving and using the natural resources for the benefit of the present and future generations; restoring, maintaining and enhancing the ecosystems and ecological processes essential for the preservation of biological diversity; raising public awareness and promoting understanding of the essential linkages between environment and development; and cooperation with other countries and International organisations and agencies to achieve these stated developments and prevent trans- boundary environmental pollution.

Diplomatic resolutions between Nigeria and Cameroon concerning the Bakassi Peninsula should be pursued to the extent of: monitoring of oceanographic processes and health of sensitive eco-systems; mitigation of coastal erosion using environmentally friendly options; coastal protection from flooding and erosion resulting from sea level rise; public enlightenment programme to the inhabitants of Bakassi for sustainable exploitation of fishery resources and development of coastal aquaculture.

\section{Agenda for Action}

What should be the priority for the Nigerian Government is to address the root causes of crisis-induced displacement, and thereby try to avoid the humanitarian crises plaguing neighbor. If such a crisis should occur in Nigeria and Cameroon, the humanitarian community at the levels of national, regional and international should in a best position to respond to the both the immediate and long term needs of the displaced people both external and internally. It is noticeable in Nigeria that the issue of internally displaced people has been neglected because of the large population size of the country and the plights of the displaced people do not make news as far as Nigeria, which is not regarded as an emergency country is concerned.

At the national level, clarification of the roles, responsibilities and division of labor between the National Emergency Management Agency (NEMA) and the National Commission for Refugees (NCR) with regard to IDP protection and assistance should be encouraged in the two countries. Nigeria and Cameroonian governments should seek technical support and training for improved emergency preparedness and response to conflict-induced displacement at both national and state level.

At state level, set up coordination structures should be set up in order to harmonize both emergency and rehabilitation response to displaced people between the various state authorities involved in a particular crisis. At the state level, there should be development of clear return and resettlement strategies that are in line with the United Nations guiding principles. Also of importance should be the improvement of overall internally and externally displaced people in order to respond to the working with UN agencies, the Red Cross and NGOs.

The coordination structures of the structures at both national and state level should be improved (e.g. participate in regular Interagency information-sharing meetings). The national and international humanitarian Organizations should be allowed full and unconditional access to displaced people both internally and externally in their places of refuge. 
The government of Cameroon and Nigeria should build upon existing peace and reconciliation efforts by promoting awareness campaigns, through local radios and other media, which focus on commonalities rather than differences between ethnic and religious groups.

In addition, they should further aid the reconciliation process by ensuring that perpetrators of the violence are identified, including members of the security forces, and they should be brought to justice. At the international level there should be the improvement of coordination of overall displaced people response at the national level by initiating regular interagency information-sharing meetings between UN agencies, relevant government bodies and NGOs, especially at the outset of a crisis.

Training and capacity building of national and state authorities (NEMA and SEMAs) through OCHA's Internal Displacement Division should be supported in order to provide technical support for the completion of a National Internally Displaced Persons' policy.

\section{Conclusion}

Adjacent to the border between Cameroon and Nigeria, the Bakassi Peninsula was the subject of a long distance diplomatic dispute between the two countries until 2002. Cameroon took the matter to the International Court of Justice (ICJ) on the 29th of March, 1994. The implementation of an ICJ ruling to ceding Bakassi peninsula to Cameroon created an unexpected wave of displacement into the neighboring states of Cross River and Akwa Ibom.

Thousands of Bakassi residents found refuge in makeshift camps or with the host families, often in precarious conditions. Although the majority of the population living on the peninsula considers themselves as Nigerians, Nigeria ceded the peninsula on 14 August 2008. Although residents could acquire full Cameroonian citizenship or opt for resident alien status), thousands of them fled following the hand-over to the neighboring Nigerian states of Cross Rivers and Akwa Ibom, fearing persecution by Cameroonian security services given previous incidents. In September 2008, some 76,000 people had registered at 12 sites in the two states. People found refuge in camps or residential areas in the interior or along coastal areas to guarantee their traditional livelihoods, while others integrated into local communities. Four main camps were set up in Akwa Ibom State, where some 2,500 former Bakassi residents have been accommodated in some vacant homes or abandoned schools, mostly without running water.

The paper examines the implications of both natural resources and displacements on the two communities, which are being analyzed from the perspectives of internal displacement within Nigeria and external displacements from the Nigeria-Cameroon borders, where the oil-rich Bakassi peninsula is located. The struggle for natural resources which is the crude oil led to crisis that degenerated into internal displacement within Nigeria while border disputes between Cameroon over oil-rich Bakassi peninsula led to crisis that culminated into external displacements of the people of both Nigeria and Cameroon borders. The complication of issues is also generated from activities of the political elites, representatives of the people and other individuals that are benefiting from the crisis.

The two governments of both Nigeria and Cameroon should build on the National IDP Policy to develop an IDP strategy. It should clearly identify the roles and responsibilities of the various humanitarian stakeholders in all phases of displacement. Awareness campaigns should be created and peace education in schools and among unemployed youths encouraged boosting reconciliation efforts. Income generation and micro-credit schemes should be developed in areas of return and resettlement of the displaced people.

\section{REFERENCES}

Africa Confidential (1994). Nigeria/Cameroon: Blundering into Battle, 35(8), pp.6. Afrique, J. (1996). Cameroon/Nigeria...La guerre secrete, No 1871, pp. 13.

Cornwell, R. (2006). Nigeria and Cameroon: Diplomacy in the Delta. African Security Review, 15(4), pp. 48-55.

Eze C., Ifeanyi, O. and Evelyn, M. (2009). Niger Delta Crisis \& Yar'Adua's Administration: Critical Issues \& Hurdles, Policy Brief of West Africa Network of Peace Building (WANEP Nigeria), Vol. 1, pp. 2.

Guy-Michel, B. (2004). Cross-Border Daries (ed.). Paris, Sud Communications. Ibeanu, O. (1998). Exiles in Their Own Home in Internal Population Displacement in

Nigeria, African Journalof Political Science, 3(2), pp. 80-97.

Imolehin A. A. (2007). Internal Shifts (Migration) in Population and Its Implications for Development Planning, Environmental Degradation and Social pressure-Case for Nigeria, Lagos, National Bureau of Statistics (NBS).

IRIN-Integration Regional Information Networks (2008). Government Unprepared for Returnee Influx. Retrieved from www.irin.org

Kirchner, S. (2004). Water, Oil and Blood: The Cameroon-Nigeria Boundary Dispute Regarding Bakassi Peninsula and Lake Chad and the Threat of War over Water Resources. Retrieved fromwww.ssm.com/author=343201.n.

Mba, T. A. (1995). Southern Cameroons Autonomy Bid, in Mbuh, M. J. (2004), International Law and Conflicts: Resolving Border and Sovereignty Disputes in Africa. Retrieved from www.postwatch.com.

Mbuh, M. J. (2004) International Law and Conflicts: Resolving Border and Sovereignty Disputes in Africa .Retrieved from www.postwatch.com

Onduku, A. (2003). Confronting The Human Security Dilemma: Towards Building Sustainable Peace In Niger Delta, Paper Presented in honour of Ms Ibiba Don Pedro, Winner of CNN 
African Journalist Award, in 2003, London ,18th October.

Price, F. (2005). The Bakassi Peninsula: The Border Dispute between Nigeria and Cameroon, ICE Case Studies, No.163.Retrieved from http://wwwl.american.edu/ted/ice/nigeriacameroon.htm. 